\section{Africa needs locally trained soil specialists to improve land use}

Sir - I commend and support Willy Verheye's suggestion in Correspondence ${ }^{1}$ that improved road systems to markets and fair price-setting will allow inland African farmers to compete better with those who sell cheaper imported foods. However, his corollary suggestion of using the "large untapped land-use potential" in this part of the world to increase food production is contrary to sensible notions of development and land management, for several reasons.

First, the few data available on land resources are unreliable. The FAO World Resources Report ${ }^{2}$ cited by Verheye was intended to highlight the global-resources aspects of the 28 major soil association groups and of their continental distribution on a 1:25 million map. Only one page (page 28) and one table (Table 11, containing some obvious errors) are devoted to land-resources reserves, and no details are given for how the data for the developing countries were obtained. The accuracy of the data at the scales used for the preparation is doubtful: each map unit includes various soil types and possible land uses ${ }^{2}$. Further, many specialists would dispute the data on cultivable reserves - for example, there is one estimate ${ }^{3}$ of possible arable expansion of 500 million ha for the whole world, which differs greatly from the 622 million ha for Africa and 696 million ha for South America in the FAO report ${ }^{2}$.

Second, current attitudes about nature conservation and development are strongly against further unchecked deforestation, which is likely to speed up soil erosion and land degradation, as well as having negative effects on biodiversity and possibly on global climate change. The remaining forests in Africa and elsewhere must be protected from further destruction, in order to promote a global sustainable geo-ecosystem. The World Bank is now rightly promoting economic development with complementary environmental conservation. African governments should follow this lead.

Yet Verheye is correct to say that solving Africa's food-production problem is, in principle, relatively simple. Food security for the growing population does not necessarily mean expansion of cultivated soil areas, but rather improved soil care and nutrient management on existing arable soils. Despite the increased production in recent decades, the average yields of cereals in Africa are still only one third of those in Europe and North America (ref. 3 and the FAO annual yearbooks). Yields per hectare of most crops in developing countries are only a fraction of what they could be under proper soil care and nutrient management, as shown by several Israeli and other demonstration projects in developing countries. Good soil care and land-use management involves soil testing, rotation, terracing and appropriate tillage, integrated with nutrient and moisture management ${ }^{4}$. Soils in practically all African countries are depleted of nitrogen, phosphorus and potassium. This nutrient depletion is probably increasing because of monocropping and insufficient resupply ${ }^{5,6}$. The vicious cycle of marginal inputs producing marginal yields resulting in marginal living standards must be broken.

In addition to improving the transport system, as Verheye suggests, the current subsidy and overseas aid should be used to provide the fertilizers and improved planting materials that are needed. Many locally trained soil and extension specialists living in the region are needed to transform the economy from one of small rural farmers to one of market food production ${ }^{7,8}$. At least ten dedicated extension soil scientists per million of rural population with problemsolving skills would be a good start.

\section{Dan H. Yaalon}

Institute of Earth Sciences, Hebrew University, Jerusalem 91904, Israel

1. Verheye, W. Nature 404, 431 (2000).

2. FAO World Soil Resources Report 66, An Explanatory Note (FAO, Rome, 1991).

3. Biswas, M. R. AMBIO 23, 192-197 (1994).

4. Yaalon, D. H. \& Arnold, R. W. Soil Science 165, 5-12 (2000).

5. Henao, J. \& Baanante, C. Estimating Rates of Nutrient Depletion of Agricultural Lands of Africa (International Fertilizer Development Center, Muscle Shoals, 1999).

6. Hartemink, A. E. Geoderma 75, 215-229 (1997).

7. Lal, R. Soil Science 165, 57-72 (2000).

8. Yaalon, D. H. Soil Science 161, 3-8 (2000).

\section{Did Greeks beat Chinese on blood circulation}

Sir - I was drawn to read P.-L. Chau's letter about the Chinese discovering blood circulation ${ }^{1}$ by the provocative title "Chinese beat Harvey on blood flow" on the contents page. Chau quoted science historian Joseph Needham ${ }^{2}$ as saying that, in the medical treatise Su Wên (part of The Yellow Emperor's Classic of Internal Medicine), "Chhi Po says that 'the flow in the tract and channel runs on and on, and never stops; a ceaseless movement in an annular circuit.... Clearly the circulation of the blood and chhi was standard doctrine [in the second century BC]".

But who is Chhi Po? According to Paul Unschuld $^{3}$, a medical historian and authority on Chinese medicine, Chhi Po or Qí Bó, the most important interlocutor of the Yellow Emperor in The Yellow Emperor's Classic of Internal Medicine, is none other than Hippocrates.

Qí Bó is a man who has no historical background in Chinese history or mythology. This fact, together with the Hàn-period pronunciation of his name, allows speculation that the fame of the Greek physician reached China two centuries after his death - to the extent that he is quoted as a living authority in medical textbooks of the time. Tsung O. Cheng

Department of Medicine, The George Washington University Medical Center, 2150 Pennsylvania

Avenue, NW, Washington DC, USA

1. Chau, P. L. Nature 404, 431(2000).

2. Needham, J. \& Lu, G. D. Celestial Lancets (Cambridge Univ. Press, Cambridge, 1980).

3. Unschuld, P. U. Chinese Medicine (Paradigm, Brookline, 1998).

\section{or was 'blood as the river of life' just poetic?}

Sir-Once again, the idea that the Chinese discovered the circulation of the blood before Harvey has been put forward, this time in Correspondence ${ }^{1}$. Joseph Needham ${ }^{2}$ does indeed quote passages from Chinese medical classics that, according to his translation, suggest the Chinese knew of the circulation of 'vital energy' (chhi, or ch'i, or qi) and that the heart acted as a pump. The problem is that Needham's translation of the passages is not accepted by other experts.

Paul Unschuld, for example, translates the same passages in a way indicating that the Chinese knew neither of the circulation of the blood (or qi) nor that the heart acted as a pump ${ }^{3-5}$.

Unfortunately, with a little stretch of the imagination and encouraged by the will to prove a point, one often can see 'proof' or suggestions of knowledge of the circulation when such proof or suggestions are not there. For example, the author of Peri kardies $^{6}$ in the Hippocratic Corpus says that the aorta and the pulmonary arteries "are the springs of the nature of man, and the rivers there move throughout the body by which the body is watered". Dante ${ }^{7}$ says "And the blood, which fills the veins, runs toward the heart which calls it."

Should we therefore conclude that Dante and the author of Perikardies had at least an inkling about circulation? Hardly. Plinio Prioreschi

Department of Pharmacology, Section of History of Medicine, Creighton University, 2500 California

Plaza, Omaha, Nebraska 68178, USA

1. Chau, P. L. Nature 404, 431 (2000).

2. Needham, J. \& Lu, G. D. Celestial Lancets (Cambridge Univ. Press, Cambridge, 1980).

3. Unschuld, P. U. Nan-ching: The Classic of Difficult Issues 14 (Univ. of California Press, Berkeley, 1986).

4. Unschuld, P. U. Medicine in China: A History of Ideas 371 (Univ. of California Press, Berkeley, 1985).

5. Prioreschi, P. A. History of Medicine Vol. I, 2nd edn, 136 (Horatius Press, Omaha, 1996).

6. Hurlbutt, F. R. Bull. Hist. Med. VII, 1104-1113 (1939).

7. Alighieri, D. Rime VI, CIII, 45-47 (Longo, Ravenna, 1995). 